\title{
Financial repression and economic distortions to the stage of economic growth and agricultural development in Bangladesh
}

\author{
S.M.A. Islam \\ Department of Business Administration, The Millennium University, Momenbagh, Dhaka-1217, Bangladesh
}

\begin{abstract}
Financial repression in a developing country is not new to us. The government may take policy for financial repression due to easy collection of inflation tax to the stage of economic development. This study is concerned to find the positive relationship between financial development and economic growth and productivity in the economy of Bangladesh. The research concluded that the financial repression has a negative relationship to the economic growth and productivity but the financial development is positively to relate the economic growth and productivity in the economy of Bangladesh. This study found evidence that the effect of financial repression is positive to the financial development in Bangladesh as it was to the high growth period in Japan. But the scenario was different for Latin American countries. Transition to the financial development from the stage of financial repression to the stage of financial liberalization is found positive to the economic growth and productivity in Bangladesh. The rural finance in agro sector is statistically significant at the level of $5 \%$ in two tail test and contributing financial sector development where the urban finance is still suffering various economic distortions to the economic growth and productivity.
\end{abstract}

Keywords: Financial Repression, Economic Distortion, Sustainable Economic Growth

\section{Introduction}

The theory and empirical evidence concluded that the financial repression has a negative effect on economic growth. But in developing country financial repression is a general phenomenon due to comply with various macroeconomic issues and easy collection of government revenue. The economic distortion caused by financial repression in a developing country is imperative to measure to the stage of economic development. What government will do if the effect of financial repression is negative to the financial development and economic growth?. We may say that the financial development is sustainable to the economic growth and productivity if the impact of financial repression is not harmful to the financial development and economic growth in long run in a country.

In the early stage of economic development, the financial repression of Japan was acutely high. Like as many developing countries, Bangladesh economy is also now a days suffering for budget deficit and inflation. The government policy maker is keen to repress financial sector due to easy collection of inflation tax. Moreover, it is argued that the government needed to impose strict control and regulation of banking system that would give the monetary authorities a better control of money supply.

In case of the history of Japanese economy, financial repression was captured the distortion of economic growth and accordingly lead the country in a substantial stage of economic and financial development during the high growth period of Japan from 1950 to 1973 . But the growth experience from Latin American countries has been found different from the rest of the countries of the world. It is a well known fact that the cross - sectional empirical studies by Barrow (1991) and others did not explain that the Latin American experience very well given that a regional dummy of this group of countries is statistically negative (Roubini and Sala-iMartin-1992). Among many explanations given in the literature of the weaker growth performance of Latin America, the systematical financial repression is more convincing (Roubini and Sala-i-Martin-1991). 
The financial development may be drastically effected and accordingly incurred a negative growth in the overall economy if the financial repression is not systematic. Does the example of Latin America is prevailing to the low income countries like Bangladesh? Is the financial repression is harmful to the sustainable financial development and economic growth in Bangladesh, so far? Is the Japanese history of financial development is the stylized fact for the financial development from the stage of financial repression to the stage of financial liberalization.

To get the answer of this research questions, we have postulated a regression model with the substantial evidence of theoretical background and economic literature. This regression model concluded that the financial repression is harmful in economic growth, but the economic distortion is still plays a positive role to the relationship between financial development and economic growth in Bangladesh. This evidence is different as it was negative in the case of Latin America (Roubini and Sala-i-Martin-1992). The constant coefficient of the regression model as a measure of financial development to the relationship between finance and economic growth. We may presume that the relationship between finance and economic growth and productivity is positive to the financial development if the constant coefficient is positive. The model proved that financial repression and economic distortion shall be captured in long run if the financial development is sustainable to the economic growth and productivity in the economy of Bangladesh. The history of financial development in Japan has the same causal relationship to the stage of economic development as it is now in Bangladesh.

Considering the theory (Roubini and Sala-i-Martin-1992) and the empirical evidence of Barrow (1991), this paper formulated a diversified econometric model to test the research questions to the relationship between sustainable economic growth and financial development in Bangladesh economy when government is keen to repress financial sectors.

Hassan, Khan, Haque (1993) produced a study on financial development and income velocity of money in Bangladesh. They found the empirical evidence that inflation and income variables affect velocity positively. But they did not produce any study to the relationship between financial development and economic growth, as well as productivity. In developing countries, financial repression is an important source of government revenue. Alberto Giovannini and Martha de Melo (1993) calculated tax revenue from financial repression equal to $1.8 \%$ of GDP for 22 developing countries over various periods spanning the years from 1972-87.

The manifold effect of financial repression causes the financial market to be inefficient. Negative real return is one of such distortion in the financial market, which was evident in Bangladesh market. Srinivasan (1988) documented negative real return on deposits in Bangladesh. Following the seminal work of Shaw and McKinnon in 1973, policy makers and international agencies accepted financial liberalization as its strategy for financial development. Financial development is defined as the extent of modernization of the economy through financial intermediation. The effect of financial liberalization is still crucial for developing countries if financial development is not sustainable to the relationship between finance and economic growth and productivity.

The government has been straggling from budget deficit and accordingly incurred the possible economic distortion through inflationary tax in Bangladesh. In this environment, there is no alternative. But still there is a question how long the financial repression is harmful but sustainable to the economic growth. Say, transition from the financial repression stage to the financial liberalization period. This paper concluded the evidence that the financial 
repression has negative relationship between economic growth and productivity. But the relationship between economic growth and financial development is positive to the stage of economic development in the economy of Bangladesh. The country has achieved the sustainability of economic development through capturing the economic distortions which was not found in the economy of Latin America. (Roubini and Sala-i-Martin-1992). But in case of Japan the scenario was positive as it is now in Bangladesh.

In this paper, the macro economic impact of financial repression on economic growth and productivity has been tasted to find the positive relationship between financial development and economic growth and productivity growth. We may take this evidence as a new finding. This may help a growing developing country to sustain in long run with a positive trend of economic growth-even there are several economic distortions due to various government intervention and natural disaster. Unfortunately, Bangladesh has been suffering several economic distortions through the natural disaster, like calamity and flood, same as in government policy, like high interest rate and high inflation, large size of the government and unavoidable corruption etc. These are highly negative for sustaining positive economic growth in long run in an economy. The financial sector development and the system stability of financial sector has become a key area of global policy makers. Financial sector development can spur economic growth whereas the financial instability can significantly harm economic growth and cause major disruptions, as we were seen in the financial crises of the 1980s and 1990s (World Bank 2001).

The banking sector embarked upon a financial sector reform in the 1990s which primarily aimed at entrusting additional powers to the central bank by strengthening the efficiency of its instruments. During the period interest rate were liberalized, open market operation was activated and attempts were also made to improve governance to the financial sector. Due to acute poverty during the early 1980 `s, the banking operation emphasized to shift financial deepening in the remote and rural areas with a view to strengthening the causality between economic growth and financial development. This policy is still should be emphasized to improve the rural economic development and stabilize the urban rural migration, and income distribution.

The financial intermediations in rural areas are found positive for economic growth but the performance of banking sector is still debatable. Access to the credit is one of the key constraints in rural finance. The rural finance is heavily based on agricultural production and agro based small and medium scale industries. More over, the finance in livestock, transportation, fisheries and housing sector are potential and the entrepreneurs appears to have projects with high rate of return, yet they are unable to obtain finance or they disappoint to take banking loan due to high interest rate and a complex legal and regulatory system.

The government policy is belongs to macro economic stabilization, therefore, the rural sector financial intermediation is still under pressure for short term government intervention to restrict money supply but, however, our concern is not the short time financial development. Since 1980`s, there is a little comprehensive technical research organized in economy of Bangladesh for financial development to evaluate the economic reform and financial repression. The financial stability and the efficiency of financial development is the key tool of sustainable economic growth. Therefore, a comprehensive measure of financial development and effective model implication of financial repression is imperative in the economy of Bangladesh to promote the sustainable economic growth, improvement of poverty and vigorous achievements of millennium development goal. 


\section{Materials and Methods}

The methodology has been divided into four steps. Step-1, we have produced the methodology of calculation of productivity growth rates, step-2, panel regression, and step-3, the dynamic panel, step-4, methods of GMM estimation to test the econometric models for the relationship between economic growth and financial development to the stage of financial repression.

\section{Calculation of Productivity Growth}

The neoclassical production function have considered in this research. There are no secondary data available for capital stock in different regions in Bangladesh. Therefore, the capital stock data has been calculated in accordance with the methodology taken by PannWorld Tables (PWT). The 'Perpetual Inventory Method' is considered here to calculate capital stock of different regions in Bangladesh as presumed by PWT. The method is as follows:

$$
K_{i, t+1}=K_{i, t}+I_{i, t}-\delta_{i} K_{i, t},
$$

Where $K_{i, t}$ is the capital stock of each region at the time $t, I_{i, t}$ is the gross investment at the

time $t_{\text {of each region } i .} \delta$, is the depreciation rate of capital of each regioni. Here, the depreciation rate has been fixed $7 \%$ on real asset as fixed for international comparison by PWT. The assumption is that this production function is common across regions and time.

$$
Y_{i}=A_{i} K_{i}^{\alpha} L_{i}^{1-\alpha}
$$

Where $Y_{i}$ denotes output at region $i$ and $K$ and $L$ stand for physical capital and labor respectively. Hence, this formulation $A_{i}$ is equivalent to TFP and $\alpha$ is a capital share. To measurement the growth of capital productivity: Prod, has been built on by the above production function. To solve the growth rate of productivity, we divide both sides of the production function by $L$, take logs and differentiate with respect to time. There is an assumption for international standard for capital share $\alpha=0.3$. We have considered this assumption for the solution of productivity growth rate of per capita; Prod= Output Growth$0.3^{\star}$ Capital Growth.

The productivity growth has been calculated on the basis of the benchmark of international standard of capital share $\alpha=0.30$. The international benchmark has been taken to compare the relationship between the capital mobility of global standard and the domestic (single country) financial intermediation. After successful calculation of the data of productivity growth by the neoclassical growth theory, the empirical model has been considered by crossregional time series of panel data, and accordingly, employ dynamic panel techniques to estimate the relationship between financial intermediation in compliance with the financial repression and economic growth and productivity.

\section{Panel Regression}

The regression estimation is produced in two separate estimate techniques. The crosssection regression without group dummy variable is produced by OLS. In analyzing dynamic panel, generalized least squares (GLS) is adopted. The two regression models are as the following: 
Cross Section Regression without Group Dummy Variables:

Basic Model:

$$
\mathrm{Y}_{i, t}=\beta^{\prime} X_{i, t-1}^{1}+\gamma X_{i, t}^{2}+\varepsilon_{i, t}
$$

Where, $Y$ represents the dependent variable, $X^{1}$ represents a set of lagged explanatory variables, these lagged variables used as instruments to control the endogenous problem and $X^{2}$ a contemporaneous explanatory variable, $\varepsilon$ is time-varying error term, and $i$ and $t$ represents the district and time period, respectively.

\section{Extended Model:}

$$
\begin{aligned}
Y_{i, t}= & \alpha+\beta_{1} F x_{u, i, t-1}+\beta_{2} F x_{r, i, t-1}+\beta_{3} Y d_{i, t-1}+\gamma_{1} F x_{u, i, t}+\gamma_{2} F x_{r, i, t} \\
& +\gamma_{3} G S D_{i, t}+\gamma_{4} I N F_{i, t}+(\text { Control..Variables })+\varepsilon_{i, t}
\end{aligned}
$$

In analyzing the panel data, two statistical estimation are commonly used, namely fixed effect model and error component model or random effect model. In this paper an error component model using GLS is adopted. The estimated region specific effect is not reported into the regression result.

\section{Extended Estimated Model:}

$$
\begin{aligned}
Y_{i, t}= & \alpha+\beta_{1} F x_{u, i, t-1}+\beta_{2} F x_{r, i, t-1}+\beta_{3} Y d_{i, t-1}+\gamma_{1} F x_{u, i, t}+\gamma_{2} F x_{r, i, t} \\
& +\gamma_{3} G S D_{i, t}+\gamma_{4} I N F_{i, t}+\gamma_{5} O P T_{i, t}+\gamma_{6} H R_{u}+\gamma_{7} H R_{r}+\varepsilon_{i, t}--------(2) \\
& \text { for } Y: \alpha>0 . . \text { and.. } \beta_{1}, \beta_{2}, \beta_{3}<0 ; \gamma_{1}, \gamma_{2}>0 . \text { and.. } \gamma_{3}, \gamma_{4}<0 ; \gamma_{6}, \gamma_{7}>0 ;
\end{aligned}
$$

The hypothesis has tested here $Y: \alpha>0$.; as a proxy of financial sector development. Here the hypothesis set $\gamma_{1}, \gamma_{2}>0$; as the positive relationship between real economic growth and finance. Same as the hypothesis set here $\gamma_{3}, \gamma_{4}<0$; as negative relationship between real economic growth and financial repression and economic distortion as per definition of variables. The detailed definitions of dependent and explanatory variables are explained in data and definition of statistical variables section.

\section{Dynamic Panel}

Dynamic Panel without Unobserved Region Effect: Cross region estimation will help us determine whether the cross-region variance in economic growth and the sources of growth can be explained by variance in the exogenous component of financial intermediary development. Unlike GMM panel procedure, such estimation suffers from potential endogeneity problems as the relationship between growth and financial development may be spurious. For the better findings, the dynamic panel with unobserved group specific effect is also taken into consideration. Here, the assumption is whether the unobserved group specific effect can produce better result, and can control endogeneity for economic growth and financial intermediary development. The equation is as follows:

\section{Basic Model:}

$$
Y_{i, t}=\beta X_{i, t-1}^{1}+\gamma X^{2}{ }_{i, t}+\mu_{i}+\varepsilon_{i, t}
$$




\section{Extended Model:}

$$
\begin{aligned}
& Y_{i, t}=\alpha+\beta_{1} F x_{u, i, t-1}+\beta_{2} F x_{r, i, t-1}+\beta_{3} Y d_{i, t-1}+\gamma_{1} F x_{u, i, t}+\gamma_{2} F x_{r, i, t} \\
& +\gamma_{3} G S D_{i, t}+\gamma_{4} I N F_{i, t}+(\text { Control..Variables })+\varepsilon_{i, t}
\end{aligned}
$$

\section{Estimated Extended Model:}

$$
\begin{aligned}
& Y_{i, t}=\alpha+\beta_{1} F x_{u, i, t-1}+\beta_{2} F x_{r, i, t-1}+\beta_{3} Y d_{i, t-1}+\gamma_{1} F x_{u, i, t}+\gamma_{2} F x_{r, i, t} \\
& +\gamma_{3} G S D_{i, t}+\gamma_{4} I N F_{i, t}+\gamma_{5} O P T_{i, t}+\gamma_{6} H R_{u}+\gamma_{7} H R_{r}+\mu_{i}+\varepsilon_{i, t}-\cdot-\cdot-\cdot \gamma_{1}, \beta_{2}, \beta_{3}<0 ; \gamma_{1}, \gamma_{2}>0 . \text { and.. } \gamma_{3}, \gamma_{4}<0 ; \gamma_{6}, \gamma_{7}>0 \text {; }
\end{aligned}
$$

The Generalized Method of Moment (GMM) is usually used to control for the endogeneity arising in panel data models. The first difference GMM estimator, as proposed by Arellano and Bond (1991), involves as a first step taking the first difference of the proposed equation in order to remove the fixed individual effects from the equation. Following Beck et al. (2000), the estimations have been used by dynamic panel GMM techniques. Besides the cross regional variance, we should also know whether changes in financial development over time within a region have an effect on economic growth through its various channels.

\section{Methods of GGM Estimation}

Hausman and Taylor (1981), Chamberlain (1984), Holtz-Eakin et al. (1990), Arellano and Bond (1991), Ahn and Schmidt (1993) and Arellano and Bover (1995) propose the GMM estimator. Arellano and Bond (1991) suggest to first difference the regression equation to eliminate the country- specific effect, as follows:

$$
y_{i, t}-y_{i, t-1}=\alpha\left(X_{i, t-1}^{1}-X_{i, t-2}^{1}\right)+\beta\left(X_{i, t}^{2}-X_{i, t-1}^{2}\right)+\left(\varepsilon_{i, t}-\varepsilon_{i, t-1}\right)
$$

This procedure solves the first econometric problem, as mentioned above, but introduces a correlation between the new error term, $\varepsilon_{i, t}-\varepsilon_{i, t-1,}$ and the lagged dependent variable, $y_{i, t-1}-y_{i, t-2}$, when it is included in $X_{i, t-1}^{1}-X_{i, t-2}^{1}$. To address this correlation and endogeneity problem, Arellano and Bond(1991) propose using the lagged values of the explanatory variables in level as error term, ${ }^{\mathcal{E}}$, and the explanatory variables $\mathrm{X}$, where $X=\left[X^{1} X^{2}\right]$, are weakly exogenous, so we can use the following moment conditions:

$$
E\left[X_{i, t-s} \cdot\left(\varepsilon_{i, t}-\varepsilon_{i, t-1}\right)\right]=0 \ldots \text { for } . . . s \geq 2 ; t=3 \ldots \ldots ., T \text {. }
$$

Using these moment conditions, Arellano and Bond (1991) propose a two -step GMM estimator. At the first step, the error terms are assumed to be both independent and homoskedastic, across specific effect and over time; at the second step, the residuals obtained at the first step are used to construct a consistent estimate of the variancecovariance matrix, thus relaxing the assumptions of independence and homoskedasticity. This is referred to as the difference estimator.

This requirement occurs because the regression in levels does not directly eliminate the region specific effect. Instead, appropriate instruments must be used to control for region specific effects. The estimator uses lagged differences of the explanatory variables as instruments. 
They are valid instruments under the assumption that correlation between $\mu$ and level of the explanatory variables is constant over time, such that

$$
E\left[X_{i, t+p} \cdot \mu_{i}\right]=E\left[X_{i, t+q} \mu_{i}\right] \ldots \text { for..all..p..and..q. }
$$

Under this assumption, there is no correlation between the differences of the explanatory variables and the region specific effect. For example, this assumption implies that financial intermediary development may be correlated with the region specific effect, but this correlation does not change through time. Thus, under this assumption, lagged differences are valid instruments for regression in levels, and the moment conditions for the regressions in levels are as follows:

$$
\left.E\left[X_{i, t-s}-X_{i, t-s-1}\right) \cdot\left(\varepsilon_{i, t}+\mu_{i}\right)\right]=0 \ldots \text { for..s }=1 ; t=3, \ldots T
$$

The system thus consists of the stacked regressions in differences and levels, with the moment conditions in equation (2) and the moment condition (4) respectively. Given that lagged levels are used as instruments in the difference regressions, only the most recent difference is used as instrument as level regression. Using additional differences would result in redundant moment conditions (see Arellano and Bover, 1995).As with the difference estimator, the model has been estimated in two step GMM procedures generating consistent and efficient estimation. Hausman test has been considered for the time varying instrumental variables which is also consistent with the Sargan specification test, Greene(2000).In case of growth models, Bond and others (2001), recommended the use of so called System-GMM estimator (Blundell and Bond 1998), which uses the information contained in the initial conditions to generate efficient estimators when $T$ is small and variables are highly persistent. The basic idea of this estimator is to use lagged first difference of the variables as instruments for the equation in levels in combination with the usual approach. However, both of the approaches in our estimation are consistent.

\section{Data and Definition of Statistical Variables}

In this section, the definition of data and variables are explained in detailed. The control variables estimated in regression model have substantial explanation in the regression estimations of Beck (2000), Rioja (2004), Barro and Sala-i-Martins`s several papers.

$Y_{i, t}=$ The real per capita growth rate of regional product. Real growth rate of per capita GRP is calculated by the Statistical Year Book of Bangladesh, Bangladesh Bureau of Statistics, Bangladesh. The per capita real GRP growth rate is calculated at constant market price of the base year 1984-85. The real GRP growth rate is calculated of 20 former districts which are treated at present of 20 administrative regional areas. In Bangladesh, these 20 former districts were established during the tenure of Pakistan rule and presently, the most influential regional areas for economic activity including sufficient infrastructure in both rural and urban areas.

$T_{F P} P_{i, t}=$ The growth rate of TFP is calculated by the data of GRP of 20 former regions. The measurement of productivity growth, prod, has been built on by the neoclassical production function. To solve the growth rate of productivity, first $L$ should divide to get per capita production. Then, it has to take log transformation and then calculate the time derivative. However, there is an assumption for international comparison for capital share $\alpha=0.3$. This assumption is considered for the solution of productivity growth rate of per capita; Prod=Growth $-0.3^{*}$ Capgrowth . 
Finance $\left(F X_{u} .\right.$. and..F $\left.F X_{r}\right)$ : The variable finance has been calculated by the data of Bangladesh Bureau of Statistics(SYB), Bangladesh. The variable finance has been calculated into two different sectors. The urban finance is defined by $F X_{u}$ and rural finance is defined by $F x_{r}$. The deposit money in all the banks of 20 former regions is taken to calculate the variable finance. The measurement of finance as deposit money bank is a proxy of financial intermediation. The regional bank branch is supposed to be permitted to channel the money into-inter bank financial adjustment. The deposit money and credit must be adjusted by the bank balance sheet. Therefore, any deposit money bank might be a good proxy of financial intermediation. Data of private credit are calculated by using the data of SYB, Bangladesh Bureau of Statistics, and Bangladesh Bank, Bangladesh and the following method:

$$
\left\{(0.5) *\left[F(t) / P_{-} e(t)+F(t-1) / P_{-} e(t-1)\right]\right\} /\left[G D P(t) / P_{-} a(t)\right]
$$

$\mathrm{F}$ is per capita deposit money bank of different sub-regions of Bangladesh with urban and rural sectors, $P$ e is the end period CPI ( Consumer Price Index), $P$ e $a$ is the average annual CPI (Consumer Price Index), GDP is per capita real growth of different sub- regions with urban and rural sectors, $t$ is representing the time difference. As otherwise, in the regression model, the lagged values also added to check the endogeneity problem as well as the time difference. In this case, deposit money might be a good predictor to compare the finance and sources of growth. Please see Beck (2000).

Openness of Trade (OPT): The openness of trade is the sum of real exports and imports and non financial services as share of real GDP. The data of openness of trade are calculated by using the secondary data of Kea Indicators of Developing Asia and Pacific Countries, ADB. There are no secondary data available of real exports and imports of 20 former regional areas. Therefore, the openness of trade is taken as equally weighted variables of 20 former regions. The openness of trade is a measure of openness to international trade and the level of integration with the rest of the world. Openness to the rest of the world provides an important channel through which the diffusion of more advanced technology from the rest of the world can potentially takes place.

In case of regional analysis, the data of Key Indicators of Developing Asia and Pacific Countries, ADB has been considered. The variable openness of trade is taken as equally weighted variable into regression estimation. Since this variable is a control variable, the finding of the estimation does not suffer but improved the result. In Bangladesh, there is no separate regulation of tariff in every region and the firm or business organization can import and export from any region.

The government trade regulation supports equally the every region and the diffusion of technology from advanced country to developing country has produced positive relationship between economic growth and productivity growth. But at the initial stage of development, the impact of openness of trade may suffer from competitive market and insufficient technological diffusion as well as can be explained by regional specific effect. However, the result may differ from country to country. But the overall impact of openness of trade is positive in cross country analysis in several researches. Please see Beck (2000), Rioja (2004), Barro and Sala-i-Martins`s several papers.

Size of the Government(GSD): Government size is real general consumption as share of real GDP are calculated by using the data of Key Indicators of Developing Asia and Pacific Countries, ADB. 
Inflation Rate (INF) Inflation rate are calculated using average annual CPI data form the Key Indicators of Developing Asia and Pacific Countries, ADB.

Human Resource $(H R)$ : The proxy of human resource is calculated by using the secondary enrollment data of SYB, Bangladesh Bureau of Statistics, Bangladesh as ratio of total population.

\section{Results and Discussion}

The empirical evidence proved that financial repression in the economy of Bangladesh is negative. The test of regression analysis has found that about 30 percent of economic distortion prevailing in the economy of Bangladesh due to large size of government and financial repression. These economic distortions have resulted 1.5 percent negative economic growth in every year to the stage of economic and financial development in Bangladesh.

But the impact of overall economic growth and financial development are sustainable. The coefficient of constant is positive to the economic growth and productivity growth (Table 1 and Table 2). For economic growth, cross section evidence of constant coefficient is 0.03298 and panel is 0.03422 respectively, which is statistically significant at the level of $5 \%$ (Table 1 ). The result shows that the size of the government and inflation is negative to the economic growth and productivity, which is theoretically acceptable. In case of productivity growth in table 2, the result is same. The constant coefficient in cross section and panel are 0.01371 and 0.01405 , respectively. These coefficients are positive and statistically significant at the level of $5 \%$ in two tail test. In this Table 2, the coefficient of inflation and size of the government is negative to the relationship between economic growth and productivity in both cross section and panel estimation.

Table 1. Economic growth and financial intermediary development-a dynamic panel with unobserved district and time Effect

\begin{tabular}{|c|c|c|}
\hline Description & $(1)$ & $(2)$ \\
\hline Dynamic Techniques & Cross-Section & Panel \\
\hline Constant: & $0.03298(0.00965)$ & $0.03422(0.00938)$ \\
\hline$F x_{\mathrm{u}, \mathrm{t}-1}$ & $-0.00336(0.00680)$ & $-0.00299(0.00613)$ \\
\hline $\mathrm{Fx}_{\mathrm{r}, \mathrm{t}-1}$ & $-0.40788(0.02817)$ & $-0.40841(0.02532)$ \\
\hline $\mathrm{Yd}_{\mathrm{t}-1}$ & $0.41123(0.02815)$ & $0.41140(0.02529)$ \\
\hline $\mathrm{Fx_{ \textrm {u } }}$ & $0.00488(0.00649)$ & $0.00464(0.00604)$ \\
\hline $\mathrm{F} \mathrm{x}_{\mathrm{r}}$ & $0.11566(0.04189)$ & $0.11637(0.04076)$ \\
\hline $\mathrm{GSD}$ & $-0.28107(0.09629)$ & $-0.29339(0.09001)$ \\
\hline $\mathrm{INF}$ & $-0.02924(0.06685)$ & $-0.02899(0.05995)$ \\
\hline $\mathrm{OPT}$ & $0.02373(0.01189)$ & $0.02322(0.01079)$ \\
\hline $\mathrm{HR} \mathrm{u}$ & $-0.01323(0.04242)$ & $-0.01508(0.03845)$ \\
\hline $\mathrm{HR}$ & $0.03915(0.02849)$ & $0.04347(0.02757)$ \\
\hline $\mathrm{R}^{2}$ & 0.61974 & 0.61960 \\
\hline Adj. $\mathrm{R}^{2}$ & 59423 & - \\
\hline Observation: & 160 & 160 \\
\hline
\end{tabular}

Note: The dependent variable is the growth rate of per capita GDP. The private credit is the credit by deposit money bank to the private sector divided by GDP. The regression variable $F x_{u}$ and $F x_{r}$ are represents private credit in urban and rural sectors, respectively. Yd is the real growth rate of per capita GDP. The term t-1 is representing one time period lagged variables. Numbers in parentheses are standard error. GSD, OPT, INF and $\mathrm{HR}_{\mathrm{u}}$ and $\mathrm{HR}_{\mathrm{r}}$ are government size, openness of trade, inflation rate and secondary enrollment ratio of total population of urban and rural sectors, respectively. 
Table 2. Productivity growth and financial intermediary development-a dynamic panel with unobserved district and time effect

\begin{tabular}{|c|c|c|}
\hline Description & $(1)$ & $(2)$ \\
\hline Dynamic Techniques & Cross-Section & 0.01405 \\
\hline Constant: & 0.01371 & $(0.00750)$ \\
\hline$F X_{u, t-1}$ & $(0.00772)$ & -0.00217 \\
\hline$F X_{r, t-1}$ & -0.00228 & $(0.00514)$ \\
\hline$Y d_{t-1}$ & $-0.00544)$ & -0.38910 \\
& -0.38889 & $0.02125)$ \\
\hline$F X_{u}$ & $(0.02254)$ & 0.39126 \\
& 0.39116 & $(0.02123)$ \\
\hline$F X_{r}$ & $(0.02253)$ & 0.00638 \\
\hline$G S D$ & 0.00643 & $0.00496)$ \\
\hline$I N F$ & $(0.00519)$ & 0.08832 \\
& 0.88938 & $-0.03260)$ \\
\hline$O P T$ & $(0.033529$ & $(0.07373)$ \\
\hline$H R_{u}$ & -0.20357 & -0.14393 \\
& $(0.07704)$ & $(0.05039)$ \\
\hline$H R_{r}$ & -0.14400 & -0.00443 \\
& $(0.05349)$ & $(0.00900)$ \\
\hline$R^{2}$ & -0.00433 & -0.28054 \\
\hline Adj. $R^{2}$ & $(0.00952)$ & $0.03211)$ \\
\hline Observation: & -0.02746 & 0.19852 \\
& $(0.03394)$ & $0.02212)$ \\
\hline & 0.01887 & 0.68322 \\
\hline & $(0.02279)$ & - \\
\hline & 0.683233 & 160 \\
\hline
\end{tabular}

Note: The dependent variable is the growth rate of per capita GDP. The private credit is the credit by deposit money bank to the private sector divided by GDP. The regression variable $\mathrm{Fx}_{\mathrm{u}}$ and $F \mathrm{X}_{\mathrm{r}}$ are represents private credit in urban and rural sectors, respectively. Yd is the real growth rate of per capita GDP. The term $t-1$ is representing one time period lagged variables. Numbers in parentheses are standard error. GSD, OPT, INF and $\mathrm{HR}_{\mathrm{u}}$ and $\mathrm{HR}_{\mathrm{r}}$ are government size, openness of trade, inflation rate and secondary enrollment ratio of total population of urban and rural sectors, respectively.

The same effect for Latin American countries of financial repression is not prevailing for the economic growth and productivity in Bangladesh. The research finding shows that the effect of financial repression by inflation tax and increase of the size of government is still sustainable for overall economic growth and productivity in the economy of Bangladesh. But the scenario of Latin American countries is not positive to sustainable economic development.

This research finding concluded that in initial stage of economic development financial repression is natural due to implementation of various government policies with a view to easy collection of inflation tax. We may treat financial sector as a stage of transition from financial repression to the stage of financial liberalization to the stage of sustainable economic growth. This economic situation was prevailed in the early stage of high economic growth period in Japan as it is now in Bangladesh. Therefore, the government of a developing country should consider financial liberalization in accordance with the demand of domestic financial development not to match with the demand of financial globalization in the early stage of economic development 
It is also justified for various reasons to adjust with financial repression as it was initiated in Japan in high growth period. The financial liberalization is essential for open market financial development and a developing country should adjust gradually economic distortions to the stage of financial liberalization process. We should be careful to keep the sustainable financial repression in the economy of Bangladesh if the financial repression is unavoidable in any circumstances to the stage of economic development. We found evidence that the finance in rural and accordingly agro sector is statistically significant at the level of $5 \%$ in two tail test in both cross section and panel estimation. These results are positive to rural growth and productivity where the urban sector is suffering various economic distortions due to lack of technology and human resource (Table-1 and Table-2).

\section{References}

Barrow, J.R. 1999. Inequality, Growth and Investment. NBER Working Paper No.7038, JEL No.04, 13.

Barrow, J.R and Sala-i-Martin, Xavier .1999. The MIT Press. Cambridge. Massachusetts. London. England.

Beck, Thorsten. Levine, Ross. Loayza, Norman.2000. Finance and Sources of Growth, Journal of Financial Economics, 58(2000): 261-300.

Balk, M. Bart .2001. The Residual: On Monitoring and Benchmarking Firms, Industries, and Economies with respect to Productivity. Statistics Netherlands Rotterdam School of Management, University of Rotterdam, P.O.Box 4000. 2270 JM Voorburg.

Bolbol, A.Ali and Sadik, T. Ali .2003. Arab External Investments: Relation to National Wealth, Estimation, and Consequences. World Developmen. 31:1771-1792.

Chen, K.Y. Edward. The Total Factor productivity Debate: Determinants of Economic growth in Asia. The Economic Development of Southeast Asia.

Fry, J. Maxwell .1998. Models of Finacially Repressed Developing Economics. World Development, 10(9):731-750.

Forsund, R. Finn .2002. On the Circularity of the Malmquist Productivity Index. The Department of Economics, University of Osloand the Frisch Centre, Oslo.

Garuda, Gopal .2000. The Distributional Effects of IMF Programs: A Cross-Country Analysis, World Development, 28(6): 1031-1051

Green William H. 2000. Econometric Analysis (Fourth Edition). Prentice-Hall, Inc .Upper Saddle River, New Jersey 07458.

Harberger, C.Arnold. 1998. A Vision of the Growth Process. The American Economic Review, 88(1).

Haque, B.M., Khan M.M and Hassain K.M. 1993. Financial Development and Income Velocity of Money in Bangladesh. The Bangladesh Development Studies, XXI(1).

Islam, Nazrul. 2001. Recent Developments in Growth Theory and Their Implications in Bangladesh. The Bangladesh Development Studies, XXVII(2).

Jones I. Charles and Hall E. Robert. 1999. Why do some countries produce so much more output per worker than others. Quarterly Journal of Economics, 114:83-116.

Kwon, K.Jane. 1986. Capital Utilization, Economics of Scale and Technical Change in the Growth of Total Factor Productivity-An Explanation of South Korean Manufacturing Growth. Journal of Development Economics, North Holland, 24 (1986):75-89.

Kwon, K.Jane. 1986. Capital Utilization, Economics of Scale and Technical Change in the Growth of Total Factor Productivity-An Explanation of South Korean Manufacturing Growth. Journal of Development Economics, North Holland, 24 (1986):75-89.

Knight Malcolm. 1998. Developing Countries and the Globalization of Financial Markets. World Development, 26(7):1185-1200.

Khandker, S.R. 2000. Savings, Information Borrowings, and Microfinance. The Bangladesh Development Studies, Vol. XXVI: (2\&3).

Maxwell, Fry, J. 1998. Money, Interest and Banking in Economic Development. The Johns Hopkins University Press, Baltimore and London.

Owyong, David. T. Productivity Growth: Theory and Measurement. APO Productivity Journal. (Downloaded from Internet) 
Pauly, P. and Marquez, J. 1987. International policy cooperation and growth progress of developing countries-an optimal control application. Journal of Development Economics, North Holland, 25(1987):89-104.

Ravallion, Martin. 2003. Measuring Aggregate Welfare in Developing Countries: How Well Do National Accounts and Surveys Agree?. The Review of Economics and Statistics, 85(3):645-652.

Quazi, M. Rahman and Alam, Imam, M. 2000. Determinates of Capital Flight: an econometric case study of Bangladesh. International Review of Applied Economics, 17(1).

Rossi, L.J.and Ferreira, C.P. 2003. New Evidence from Brazil on Trade Liberalization and Productivity Growth, International Economic Review, 44(4).

Schumpeter, Joseph A. 1912. The Theory of Economic Development ; An Inquiry into Profits, Capital, Credit, Interest, and the Business Cycle. Translated by Redvers Opie. Cambridge, Mass: Harvard University Press, 1934.

Sala-i-Martin, Xavier and Nouriel, Roubini. 1992 .Financial repression and economic growth, Journal of Development Economics, North- Holland, 39(1992): 5-30.

Stiglitz, E.J. 2000. Capital Market Liberalization, Economic Growth, and Instablity, World Development, 28(6):10751086.

Valev, Neven and Rioja, Felix.2004. Finance and the Sources of Growth at Various Stages of Economic Development, Economic Inquiry, Vol(1): January 2004, 127-140.

Wodon, T.Q. 1999. Micro Determinants of consumption, poverty, growth and inequality in Bangladesh, World Bank. 